\title{
OFFSHORE FINANCING: THE NATURE OF SECURITY INTERESTS IN OIL AND GAS PROJECTS ON THE CONTINENTAL SHELF
}

\author{
F. V. W. (VAN) PENICK*
}

This paper examines the nature and extent of oil and gas rights on the continental shelf which can be assigned to lenders as security for project development loans.

\section{INTRODUCTION}

At least one offshore hydrocarbon reserve, the natural gas field at Sable Island, is poised at the development threshold and the interest holders are beginning to focus their attention on the financing arrangements which will be required to support expenditures in the range of three billion Canadian dollars.' ${ }^{\prime}$ This paper considers the nature of the interests which the holders can give lenders as security for the substantial indebtedness that will be incurred several years before production commences and any cash flow from the project is achieved.

The nature, quality and enforceability of the security will be of particular importance if loans are arranged on a non-recourse project financing basis, where the lender's right to repayment is primarily, if not entirely, dependent upon the ability of the project to generate income, and the lender's security is comprised of the project's assets and receivables.

We shall examine the scope of the rights and powers over the of fshore which international law accords to a coastal nation, the division of those rights and powers between the federal and provincial governments in Canada, the nature of the rights granted to an interest holder under the Canada Oil and Gas Act, ${ }^{2}$ and the manner and extent to which those rights can be assigned to a lender as security for the repayment of a loan.

\section{INTERNATIONAL LAW}

As the Supreme Court of Canada stated in the Hibernia Reference with respect to the continental shelf off Newfoundland: ${ }^{3}$

[t]he rights claimed [by Canada and Newfoundland] are those accorded by operation of international law.

and:

. . . in the continental shelf the limited rights that international law accords are the sum total of the coastal state's rights.

If Canada's rights in the continental shelf were acquired not through preconfederation colonial law or post-confederation constitutional law, but rather through the development of international law, then the nature of the rights which international law accords to a coastal state must be examined.

- Partner, Mclnnes, Cooper \& Robertson, and Lecturer in Oil and Gas Law, Dalhousie University, Halifax, Nova Scotia.

1. Peter A. Outhit, "Natural Gas Sales and Transmission Risks" (1984) International Bar Association, Sixth Energy Law Seminar.

2. Canada Oil and Gas Act, S.C. 1980-81-82-83, c. 81.

3. Newfoundland Reference Re Continental Shelf(1984) SI N.R. 362 at 367,368 (S.C.C.). 
Article 2 of the 1958 Geneva Convention on the Continental Shelf, which was ratified by Canada in 1970, is identical to Article 77 of the recently-concluded United Nations Convention on the Law of the Sea. Sub-Article (1) of each Article defines the rights of a coastal state over the natural resources of its continental shelf: ${ }^{4}$

1. The coastal State exercises over the continental shelf sovereign rights for the purpose

of exploring it and exploiting its natural resources.

Therefore, to determine the nature of the interests an oil company may have pursuant to a production licence granted by a coastal state, it is necessary first to determine what rights comprise sovereign rights to explore and exploit the natural resources of the continental shelf.

The years preceding the 1958 Geneva Convention witnessed a somewhat heated international debate on the use of the word "sovereign", as opposed to the word "exclusive", in describing a coastal state's rights to explore and exploit.

The United States had focussed international attention on the continental shelf with the Truman Proclamation of 1945 , by which the United States claimed only a limited jurisdiction over the shelf. It is apparent that Washington had gone to considerable pains, in preparing the Truman Proclamation, to preserve to the maximum possible degree the principle of the freedom of the high seas. Other countries promptly declared their entitlement to their continental shelves, but many claimed vastly greater rights, including full sovereignty over the water column, the submarine areas and the superjacent air space. Consistent with its position of limited jurisdiction, the United States advocated the use of the word "exclusive" to qualify the nature of a coastal state's right to explore and exploit its continental shelf. As Marjorie Whiteman has observed: 5

It was well known, of course, that certain states desired that rights with respect to the continental shelf should affect the legal status of the waters above the shelf and the superjacent airspace. In that light, at least, it seemed desirable to some states. including the United States, to "play it safe" by avoiding the use of the term "sovereignty", or even "sovereign rights" in defining the relation of the coastal state to the continental shelf.

... The United States proposed .. . the deletion of the word "sovereign" and the substitution of the word "exclusive" . . In introducing the Delegation's proposal, the U.S. representative made it clear that the U.S. Delegation was opposed to anything which might even remotely cast doubt upon the status of the superjacent waters and airspace.

By including in the Convention an express provision confirming the freedom of the high seas, the United States was persuaded to adopt the adjective "sovereign".

It is submitted that the qualification of a coastal state's rights in the natural resources of its continental shelf was intended not to restrict the state's powers over the development of those resources, but rather to confine those powers to the resources alone, to preserve the traditional

4. Convention of the Continental Shelf. done at Geneva. 29 April. 1958. Art. 2 (1) and Lau of the Sea Convention, done at Montego Bay, Jamaica. 6 December 1982. Art. 77 (1).

5. Marjorie M. Whiteman, "Conference on the Law of the Sea: Convention on the Continen(al Shelf" (1958) Vol. 52. The American Journal of International Law 629 at 636. 
freedom of the high seas, the water column and the superjacent air space. As the Supreme Court of Canada stated in the Hibernia Reference: ${ }^{6}$

International law was forced to take note of the continental shelf when, in the middle of this century, the technology was developed to exploit offshore resources. A consensus developed that the exploitation should be under the control of the coastal state. The 1958 Geneva Convention was drafted so as to do no more than was necessary to achieve this result. Thus the Convention does not grant "sovereignty" over the continental shelf but rather "sovereign rights to explore and exploit". These limited rights co-exist with the rights of other nations to make use of the seabed for submarine cables and pipelines (Article 4) and do not affect the status of the superjacent waters or airspace (Article 3 ).

Having confined continental shelf rights to jurisdiction over the natural resources themselves, the nations ratifying the 1958 Convention preferred the wider connotations of the term "sovereign" rights to explore and exploit to the perhaps narrower term "exclusive" rights, so that a coastal state would possess every power necessary or desirable to develop the natural resources of its continental shelf. It is further submitted, then, that so long as the freedom of the high seas and of the superjacent water column and air space is preserved, a coastal state may be able to assert real property interests in oil and gas in place under its continental shelf without violating international law.

This opinion is supported by the attitude of the North Sea countries respecting the oil and gas deposits which traverse international boundaries in that region. In a series of bilateral treaties', the North Sea states have developed an approach which:

1. recognizes a state's interest in the petroleum deposits straddling international boundaries;

2. recognizes the migratory nature of oil and gas, not by adopting the rule of capture found in parts of the United States and Canada, but by imposing on the interested states an obligation to negotiate a joint operating and revenue-sharing agreement under which the deposit will be produced; and

3 . in one case, ${ }^{8}$ recognizes one state's right to compensation if the neighbour state unilaterally develops and takes production from the common reservoir.

In light of these conventions, treaties and international practices, it is difficult to imagine a consistent theory of coastal state rights in the natural resources of its continental shelf which does not admit of substantial rights in the oil and gas in place, rights which a state can grant to a licensee and which a licensee, in turn, can pledge as security for a loan.

It must be conceded, however, that while in situ rights may be inferred as a logical extension of continental shelf law, in situ rights have not been recognized explicitly. Until international customs further solidify, a coastal state may be wiser to withhold internal acknowledgement and regulation of such rights.

6. Supra n. 3 at 367.

7. See William T. Onorato. "Apportionment of an International Common Petroleum Deposit" (1977) 26 I.C.L.Q. 324 at 325-326 n. 6.

8. Id. at $329 \mathrm{n}$. 1S. Art. 2 (2) of the 1971 Treaty between the Federal Republic of Germany and the Kingdom of Denmark. 
[VOL. XXIII, NO. ]

In Canada, rights conferred on explorers and producers of oil and gas from the continental shelf do not include real property rights in the hydrocarbons, and while this may well be the safer course, the implications of the reservation of these rights are discussed below. ${ }^{9}$

\section{CONSTITUTIONAL ALLOCATION OF CONTINENTAL SHELF RIGHTS}

Having considered the nature of continental shelf rights and powers exercisable by a coastal state, the next step is to examine the allocation of those rights and powers between the federal and provincial levels of government in Canada. Although recent developments have resolved some of the long-standing and bitter jurisdictional conflicts between $\mathrm{Ot}$ tawa and the coastal provinces, Canada does not yet enjoy the luxury of a complete and harmonious settlement.

Briefly, the 1967 British Columbia Offshore Minerals Reference ${ }^{10}$ stands for the proposition that unless a province's boundaries have been altered by one of several reasonably specific procedures since it joined Confederation, the province has only those limits and proprietary rights which it enjoyed immediately prior to Confederation. Since, at common law, the provinces' rights end at the low water mark, a province must prove that its rights were extended, either by express delegation from the Imperial Crown, or by some other principle of colonial law, or, in the case of Newfoundland, by acquisition through its status as an independent nation under international law. British Columbia was unable to demonstrate any such extension and the Supreme Court of Canada held that the federal government was entitled to all legislative and proprietary rights exercisable by Canada in the territorial sea and continental shelf off the west coast.

The question referred to the Supreme Court of Canada in the 1967 Reference dealt only with the territorial sea and continental shelf. The Court was not then asked to determine federal and provincial rights in the internal waters between the land mass and the territorial sea. It has since been asked to consider this issue and to formulate a definition of those internal waters in the Georgia Strait Reference." The appeal was heard in September of 1982 but, at the time of writing, judgment had not yet been pronounced.

The Nova Scotia continental shelf is the subject of a political agreement executed by Prime Minister Trudeau and Premier John Buchanan on March 2, 1982. ${ }^{12}$ The Agreement expressly sets aside the legal question of ownership and legislative control. ${ }^{13}$ It provides that the Canada Oil and Gas Act will apply to the offshore area, ${ }^{14}$ with certain provincial in-

9. Infra at Part IV. esp. text accompanying n. 23 et. seq.

10. Reference Re Offshore Mineral Rights of British Columbia [1967] S.C.R. 792.

11. A.G. Can. v. A.C. B.C. $(1984) 4$ W.W.R. 289 (S.C.C.).

12. Canada - Nova Scotia Agreement on Offshore Oil and Gas Resource Management and Revenue Sharing. 2 March 1982, reproduced in C.C.H. Canadian Lid. Energy Program Reporter.

13. Id. at s. I.

14. Supra n. 12 at ss. 3 and 17. 
put injected through the establishment of a joint Board. ${ }^{15}$ However, since the Agreement has not been implemented by appropriate legislation, it is put in ever increasing jeopardy by the passage of time, threatened by a possible change of government or a change of leadership within that government. ${ }^{16}$

The reverse of the Nova Scotia situation presently prevails in Newfoundland, namely, a legal determination without political concurrence. The Hibernia Reference, decided on March 8, 1984, denies the Province of Newfoundland any proprietary or legislative right over the continental shelf: the Supreme Court of Canada heid that the federal government has exclusive jurisdiction with respect to Canada's sovereign rights to explore and exploit the shelf's natural resources. 17 The question submitted by the Governor in Council dealt only with a small area surrounding the Hibernia oil field on the Grand Banks, but it is clear that the judgment extends with equal force to the entire Newfoundland continental shelf. However, the Supreme Court of Canada did not consider the status of internal waters or the territorial sea. The Newfoundland Court of Appeal has held that the internal waters and a three-mile band of territorial sea belong to Newfoundland. ${ }^{18}$ Appeals from this decision have been filed in Ottawa but, at the time of writing, had not been set down for hearing.

Accordingly, some questions remain unanswered, but with the 1967 British Columbia Offshore Minerals Reference, the 1982 Canada-Nova Scotia Offshore Agreement and the 1984 Hibernia Reference, the federal-provincial jurisdictional conflict has been resolved with sufficient certainty that the federal government is clearly in a dominant position with respect to its negotiations with coastal provinces and to its authority to implement natural resource development legislation of the shores of both coasts. It has exercised this authority primarily through the Canada Oil and Gas Act, ${ }^{19}$ and it is submitted that chances of a successful constitutional challenge to its validity are now so remote as to merit little practical concern.

\section{THE CANADA OIL AND GAS ACT}

The Canada Oil and Gas Act was proclaimed in force on March 5 , $1982.20 \mathrm{It}$ applies to all "Canada lands", which are defined in subsection 2(1) as:

\footnotetext{
"Canada lands" means lands that belong to Her Majesty in right of Canada, or in respect of which Her Majesty in right of Canada has the right to dispose of or exploit the natural resources and that are situated in
}

15. Id. at s. 3.

16. Legislation implementing the Offshore Agreement has now been passed: the Canada Nova Scotia Oil and Gas Agreement Act, S.C. 1983-84, c. 29. The only provisions proclaimed in force as of July 1, 1984 relate to the imposition of provincial sales tax of fshore. Generally, the legislation is comprehensive. although one matter of major importance. the extension of provincial laws generally to the offshore area (s. 17 of the Agreement). has been omitted.

17. Supran. 3.

18. Reference Re Mineral and Other Natural Resources of the Continental Shelf (1983) its D.L.R. (3d) 9 (NfId. C.A.).

19. Supra n. 2.

20. Id. 
(a) the Yukon Territory or the Northwest Territories, or Sable Island, or

(b) those submarine areas, not within a province, adjacent to the coast of Canada and extending thröghout the natural prolongation of the land territory of Canada to the outer edge of the continental margin or to a distance of two hun. dred nautical miles from the baselines from which the breadth of the territorial sea of Canada is measured. whichever is the greater.

The Minister of Energy, Mines and Resources may enter into exploration agreements respecting Canada lands, and if certain conditions are met, he is required to grant production licences. ${ }^{21}$ These interests granted under the Canada Oil and Gas Act replace oil and gas rights granted prior to March 5, 1982, ${ }^{22}$ although former holders are given the right to negotiate new exploration agreements or to apply for provisional leases. ${ }^{23}$

The rights granted pursuant to the Act are consistent with the rights recognized by international law, as discussed above. The geographical extent of the Act clearly complies with international law, as Canada lands are restricted, first, to lands whose natural resources the nation of Canada has the right to regulate, and secondly, to a submarine area defined in terms which are virtually identical to Article 76(1) of the 1982 United Nations Law of the Sea Convention. ${ }^{24}$

Similarly, the rights which Canada purports to exercise within that geographical area are defined with an apparent intent to conform to international law. Sections 9 and 17 of the Act relate to exploration and exploitation, respectively, and provide as follows: ${ }^{25}$

\begin{abstract}
9. An exploration agreement confers. with respect to the relevant Canada lands. the right to explore for and the exclusive right to drill for oil or gas. the exclusive right to develop those Canada lands in order to produce oil or gas and the exclusive right. sub. ject to compliance with the other provisions of this Act, to obtain a production licence.

17. A production licence confers, with respect to the relevant Canada lands, the exclusive right to produce oil or gas and, subject to section 48 and to the payment of any applicable royalty to Her Majesty in right of Canada. confers title to the oil or gas so produced.
\end{abstract}

No exclusive right to occupy the area covered by an agreement or licence is given, and no traditional words of conveyance are used. The presence of the word "licence" instead of "lease" further indicates an intention to deal in rights of a contractual rather than real property nature.

A right in a mineral in situ is a right in real property, but when the mineral is extracted from the ground, it is severed from the realty and becomes personal property. ${ }^{26}$ Since a production licence only confers title to oil and gas once it has been produced, the interest acquired by a licensee is personal rather than real.

Aware that it has only the sovereign right to explore and exploit the natural resources of the continental shelf, the federal government has established a regime of offshore oil and gas exploration, development and production which does not vest real property rights in any holder of

21. Id. at s. 18.

22. Id. at s. 61 .

23. Id. at 5.63 .

24. Supran. 4 at Art. $76(1)$.

25. Supran. 2 at ss. 9 and 17.

26. See Atlantic Concrete Lid. v. MacDonald. Lavatte Construction Co. Lid. et al(1975) 12 N.S.R. (2d) 179 (N.S.S.C.. App. Div.). 
an exploration agreement or production licence. This will obviously affect the form of documents used to secure loans or transfer interests, and although there is little theoretical difference between the extent of the rights which can be created in respect of real property and personal property, the wide discretionary powers retained by the government under the Canada Oil and Gas Act are more compatible with a contractual framework of negotiated terms than with a real property framework of absolute demise.

A potential lender to an offshore hydrocarbon project must evaluate the rights his borrower is able to offer as security. The right to produce oil and gas under the Act is contractual in nature. Personal property rights are less certain and less permanent than a grant in fee simple, but they are substantive rights, nonetheless. Under the Act, these rights include: the exclusive right to produce, title to the hydrocarbons so produced and a ten-year production term, renewable so long as the field is capable of production. There are, however, significant reservations and uncertainties set out in the Canada Oil and Gas Act which affect some of these rights and their value as security, and it is the quality of these rights as security which must next be examined. This examination will reveal a curious difference under the Canada Oil and Gas Act between the treatment of the two types of interest - "undivided" and "divided" interests - which may be acquired in production licences and exploration agreements.

\section{UNDIVIDED INTERESTS UNDER THE CANADA OIL AND GAS ACT}

The Act defines an "interest" as an exploration agreement or a production licence ${ }^{27}$ and a "share" as an undivided share in an interest. ${ }^{28}$ An "interest holder" holds an interest or a share in an interest ${ }^{29}$ and an "interest owner" is the group of interest holders who hold all the shares in an interest. ${ }^{30}$

Lenders to holders of undivided shares will pay careful attention to the following qualifications on their borrowers' rights.

\section{A. RIGHTS TO PRODUCTION LICENCE}

If the borrower is seeking funds prior to receiving a production licence, the lender will require assurances that two conditions precedent to the grant of a licence will be met:

1. The Minister must be satisfied that a commercial discovery extends to the lands sought to be licenced. ${ }^{31}$ This should not present any difficulty since, presumably, development funds will not be needed unless and until there is a commercial field.

27. Supran. 2 at ss. 2 (1).

28. Id.

29. Id.

30. Id.

31. Id. at s. 18. 
2. The beneficial owner or owners of the licence must have a Canadian Ownership Rate (COR) of at least $50 \%$. Paragraph $19(1)(\mathrm{c})$ and section 21 of the Act provide that where there is more than one owner, the Canadian Ownership Rate of the group will be each holder's COR multiplied by his percentage share of the licence. Consequently a non-Canadian company can be a holder of a share in a licence, provided that the average COR is $50 \%$ or more. Lenders will require COR certificates of every interest holder, not just that of their borrower, and will likely require further assurances respecting restrictions on share transfers, mergers, amalgamations, forfeiture of shares, options and other arrangements which could lower the COR. Lenders may also require guarantees or indemnifications from parent corporations or other affiliates to protect against the possibility that the licence will not be issued to the borrower, an event that would surely result in irretrievable loss.

\section{B. ASSIGNMENT AND REGISTRATION OF SECURED INTERESTS}

Once satisfied that a licence will be granted, the lender's next concern is to perfect and register his security interest. Subsection 52(1) of the Act makes it essential to obtain Ministerial approval before funds are advanced:

s2(1) Where an interest holder ... proposes to enter into an agreement or arrangement that may result in a transfer, assignment or other disposition of an interest or a share in an interest, the interest holder shall give notice of such agreement or arrangement to the Minister . . . and no such agreement or arrangement shall have any force or effect with respect to such transfer, assignment or other disposition until it is approved or deemed to be approved under this section.

The Minister may reject a proposed transfer on any grounds he considers to be in the public interest or, more specifically, if he is of the opinion that the proposed transfer might diminish the group owners' average COR below 50\%.32 To gain Ministerial approval, then, foreign or other low-COR lenders may have to undertake that they will dispose of any realized secured interest to Canadians within a certain length of time.

Section 53 of the Act provides that "no interest or share in an interest passes without registration in the manner prescribed". Reasonably straightforward registration regulations have been passed..$^{33}$ They require the Minister to maintain a register ${ }^{34}$ and to record therein approved agreements and arrangements that may result in a disposition of an interest or a share in an interest. ${ }^{35}$

The chief question here is whether security under section 177 of the Bank Act ${ }^{36}$ must be approved by the Minister and registered under the Canada Oil and Gas Act before it is effective according to its terms. Subsection 177(1) authorizes a bank to lend on the security of hydrocarbons or minerals, rights to produce these substances, equipment used in

32. Id. at ss. 52 (3).

33. Canada Oil and Gas Interests Regulations, SOR/83-151.

34. Id. at Reg. 6 (1).

35. Id. at Reg. 6 (2).

36. Bank Act, S.C. $1980-81-82$, c. 40 . 
extracting or seeking to extract these substances or ariy partial rights or interests in any of the foregoing. Subsection 177(2) sets out the form of the security document and subsection 177(3) describes the bank's remedies on non-payment of the loan or failure to preserve the value of the secured assets. On such default, the bank has the right to take possession of the secured assets, to use them and, subject to the provisions of any other Act governing the ownership and disposition of the secured assets, to sell them. Accordingly, even if registration of section 177 security was not required, any disposition by a lender of a realized security interest would be subject to Ministerial approval under section 52 of the Canada Oil and Gas Act.

Nothing in the Bank Act makes registration of a section 177 security necessary in order to perfect it, although in order to maintain its priority over subsequent interests, a bank must comply with applicable provincial registration requirements and any federal enactments which specifically refer to section $177 .{ }^{37}$ It has been observed that since the Canada Oil and Gas Interest Regulations make no reference to section 177, registration pursuant to section 53 of the Canada Oil and Gas Act is not a condition to the maintenance of the priority of the security. ${ }^{38}$ However, there will be no priority to maintain unless, in the first place, the borrower can validly pass a security interest to his bank. And section 53 provides that, without exception, no interest or share in an interest passes unless it is registered.

Whereas a provincial statute requiring registration could not deprive a bank of its federally-bestowed security rights under section 177 , the Canada Oil and Gas Act is a federal statute. The section 53 registration requirement is probably not inconsistent with the Bank Act, since it only adds a further requirement in the course of perfecting a section 177 security. Even if the two provisions were considered to be inconsistent, the section 53 registration requirement would probably prevail, because the Canada Oil and Gas Act was enacted over a year after the Bank Act. The governing principle of statutory interpretation was enunciated by the Chief Justice of Nova Scotia in the 1979 case of Ells v. Ells: ${ }^{39}$

\footnotetext{
... we must make both statutes work together unless by necessary implication the earlier statute, or some part of it, is so inconsistent with the later statute that we must say that the Legislature intended the later to replace and render inoperative the earlier inconsistent part.
}

Furthermore, mandatory registration of section 177 security under section 53 will make it possible for a lender to a partial interest holder to evaluate the security interests held by other lenders to other interest holders. As discussed below, it is a vital concern to a lender to know who the other secured lenders are.

37. Id. at ss. 177 (8).

38. R.J. Thrasher. "An Update on the Canada Lands" (1983) Canadian Tax Foundation, Recent Developments in the Tax Treatment of the Petroleum Industry: A Technical Analysis at 258 to 259.

39. Ells v. Ells (1979) 99 D.L.R. (3d) 686 al 688 (N.S.S.C., App. Div.), quoted with approval in Elmer A. Driedger. Construction of Statutes (2nd ed. 1983) 226 to 227. 


\section{LOW-COR REDUCTION OF INTEREST}

If the COR of the holders of a production licence falls below $50 \%$, the Minister is empowered to take a share in the licence equal to the difference between $50 \%$ and the actual COR percentage. The share is taken from the holders pro rata and is held by the Minister "free and clear of all dependent rights". ${ }^{40} \mathrm{~A}$ "dependent right" is defined in subsection $30(2)$ of the Act as:

30(2) "Dependent right" means any right, encumbrance or other consideration in. relating to, dependent on or calculated by reference to the share or production in respect of or imputable to the share of an interest holder, but does not include any debt or other obligation secured by an encumbrance.

Thus a lender's security interest can be diminished by some unforeseen increase in foreign shareholdings, not only of its own borrower, but also of any of the other interest holders, or by an assignment from any interest holder to a holder with a lower COR, or by a realization of a security interest by any lender whose COR is lower than its borrower's. ${ }^{41}$ To protect itself, a lender will require satisfactory COR representations from each licence holder and each licence holder's lender together with covenants to maintain such Canadian Ownership Rates and prohibitions against assignments to anyone, including other existing holders, or to parent, subsidiary and affiliated companies, without the consent of the lender. Depending upon the circumstances, a lender may also require guarantees from a parent company that it will make up any losses occasioned by a reduction in interest.

For instance, assume that, after the Crown back-in discussed below, a subsidiary exploration company holds a $30 \%$ undivided interest in a production licence. That company's lender may require its parent company, in the event that the subsidiary's share is reduced below $30 \%$ by the operation of section 23, to indemnify the lender against the value of the lost share of production and in the case of realization, the value of the lost interest.

The difficulty with this indemnification is that it constitutes a "dependent right" within the meaning of section 30 , as it is a right held by the lender calculated by reference to the share (or production in respect of or imputable to the share) of an interest holder, and it is not a debt secured by a charge on a share of the production licence.

The indemnification would, therefore, be subject to subsections $30(1)$ and $30(3)$. Subsection $30(1)$ provides that where a holder's share is reduced:

1. any dependent right in respect of that share is proportionately reduced;

2. any agreement inconsistent with such a reduction is deemed amended to give ef fect to the reduction; and

3. no interest holder is liable for the reduction.

40. Supran. 2 at s. 23.

41. G.G. Wickerson. "Canada Oil and Gas Act" (1982) Canadian Tax Foundation. Tas Treatment of the Petroleum Industry Under the National Energ. Program 129. 
The intention of subsection $30(1)$ is to ensure that a default cannot arise under a loan agreement on account of a COR reduction. But in the above example the result would be the total assumption of risk by the lender.

Parliament has provided a somewhat uncertain way around the very restrictive effect of subsection 30(1). Subsection 30(3) allows the lender and a holder of a share, by giving the Minister appropriate notice, to agree that paragraphs $30(1)$ (a) to (c) will not apply, but subsection $30(3)$ also provides that nothing in such an agreement shall:

.. . have the effect of making dependent rights in respect of that share exceed the share of the interest remaining after such reduction.

Notice to the Minister is the only prerequisite to exception from s.30(1); the Minister is not given the power to reject such an agreement. However, the agreement must be between the interest holder and the lender. In the above example, the guarantee is given by the parent company, but the agreement to exclude the operation of subsection 30(1) must be made between the lender and the interest-holding subsidiary. The uncertainty arises from the difficulty in trying to determine whether a lender's rights under a parent company's guarantee "exceed" a subsidiary's undivided interest in a production licence. This provision in subsection 30(3) was probably intended to ensure that if a holder's interest is reduced, for example, from $30 \%$ to $29 \%$, then without qualification, a lender cannot hold a charge on any interest which exceeds $29 \%$. But it is submitted that the definition of "dependent right" is so broad that virtually every obligation undertaken by an interest holder under a loan agreement must be carefully reviewed to determine if it stands to be diminished as a result of a low-COR reduction and if it can be maintained despite such a reduction by notice to the Minister.

To protect its interest in the event of a low-COR interest reduction, a lender might seek a commitment from the Minister prior to the advance of funds that a low-COR notice will be sent to the lender as well as the interest owner and that the lender itself may have reasonable time to raise the COR of the group of interest holders. The lender may then require in the loan agreement with its borrower that the borrower will, for example. issue new shares to Canadians, or will compel his fellow interest holders to do likewise.

\section{CROWN SHARE AND ANCILLARY RIGHTS}

The reservation of a $25 \%$ Crown share in all exploration agreements and production licences ${ }^{42}$ is one of the most controversial provisions in the Canada Oil and Gas Act, but as it stands, its impact on lenders is not open to much doubt. Although an exploration agreement may describe "A Co." as the $100 \%$ undivided interest holder, "A Co." has only a $75 \%$ interest, for subsections $27(2)$ and (3) reserve to the Crown a 25\% share in every exploration agreement, production licence or other interest created under the Act. Further, since the Act revokes all prior interests, the reservation is comprehensive. It cannot be argued that the Government waives its share by entering into an exploration agreement which does not refer to the Crown back-in, because the federal government has 
$\cdot$ [VOL. XXIII, NO. 1

no power to abandon its $25 \%$ interest. Prior to production, the federal government may transfer the Crown share to a Crown corporation ${ }^{43}$ and the Crown corporation may convert the Crown share into an ordinary $25 \%$ undivided interest. If either the transfer or the conversion does not occur, the federal government must dispose of the interest by public tender. ${ }^{45}$ It cannot simply give up the Crown share.

Consequently, every lender must be aware that every one of its borrowers' interests in Canada lands is subject to the Crown share, and must be evaluated as such. A $40 \%$ interest calculated without reference to the Crown share is a $30 \%$ interest in reality, despite the obligation of the holder to pay $40 \%$ of the exploration and development costs incurred before the designated Crown corporation converts the Crown share to an ordinary $25 \%$ working interest. ${ }^{48}$

A disturbing aspect of the Crown share provisions is that once the Crown share has been transferred, the Minister may direct that the designated Crown corporation will be the operator of the interest. ${ }^{47}$ Such appointment will force the Crown corporation to convert its Crown share to an ordinary interest, ${ }^{48}$ so that the Crown corporation will at least have to pay $25 \%$ of the expenses which it oversees as operator.

The lender to a Canada lands interest holder cannot, therefore, rely in his evaluation of the project upon the operation of that interest by, for example, a particularly experienced and efficient operator, even if all the interest holders agree. The lender must be aware that operations can be taken over unilaterally by Petro-Canada or any other corporate agent of the Crown designated by the Minister.

\section{E. PRODUCTION ORDERS}

Subsection 48(1) of the Canada Oil and Gas Act gives the Minister the widest possible discretion to set the rate of production, the price to be charged and the allocation of the hydrocarbons so produced:

48(1) Where the Minister is of the opinion that it is in the public interest. he may, by order subject to section 56, require any interest owner specified in the order

(a) who, in the opinion of the Minister, has the capability to produce oil or gas from the Canada lands subject to his interest, to commence. continue or increase production of oil or gas, for use in a Canadian domestic market and deliver the oil or gas so produced at the times and places and in the quantities specified in the order. for sale to persons specified in the order, at the prices specified in the order, or

(b) who is producing oil or gas from the Canada lands subject to his interest, to produce oil or gas at such rates and for such periods as may be specified in the order or to decrease, suspend or cease such production for such periods as may be specified in the order, and to decrease. cease or suspend. for any periods specified in the order, any work or activity that is inconsistent with any thing specified in the order, whether or not that work or activity is carried out under a contract for the disposal of oil or gas or under any other obligation or commitment.

43. Jd. at s. 31 .

44. Id. at s. 36.

45. Id. at ss. 32 and 37 .

46. Id. at ss. 36 (3).

47. Id. at ss. 35 (1).

48. Id. at ss. 35 (4). 
This power will cause great anxiety in the corporate hearts of lenders. The certainty of long term purchase and sale contracts, particularly of natural gas, is a prerequisite to the availability of non-recourse project financing, and the assignment of receivables under those contracts is perhaps the most substantial security a lender of project financing can take.

The lender's security is further weakened by subsection $48(4)$, which protects a borrower against any liability arising from compliance with a Ministerial production order. Unlike the low-COR interest reduction discussed above, ${ }^{49}$ the Act does not contain a provision enabling a borrower and a lender to agree that subsection 48(4) will not apply.

One of the consequences of the Ministerial power to determine production rates and prices is that large companies, with additional assets besides the project's sales contracts to pledge as security, will have an advantage over smaller companies. This consequence seems to contradict the "Canadianization" goals of the National Energy Program.

Undoubtedly, interest holders and their lenders will seek from the Minister concrete assurances that his discretion will be exercised only in defined circumstances, such as a severe disruption in world energy supplies or for national defence purposes in time of war.

\section{F. CANCELLATION OF RIGHTS}

Where the holder of an undivided interest in an exploration agreement or a production licence fails to comply with a Ministerial notice to cure some default in its statutory obligations, the Minister is authorized by subsection $55(2)$ of the Act to cancel the interest or transfer it "free and clear of all dependent rights" to the Crown. This is another far-reaching Ministerial power, one which can be exercised for the slightest default. The lender again will attempt to negotiate with Ottawa a narrowing of the conditions under which the Minister will cancel or transfer the interest, and a commitment to notify the lender as well as the borrower of default so that the lender will have the opportunity to remedy the default and protect its security.

Because the Government retains such extensive powers under the Canada Oil and Gas Act, interest holders and their lenders will have to seek binding commitments in respect of the exercise of such powers. Without substantial concessions from the federal government to restrict the exercise of those powers to defined circumstances, interest holders will encounter great difficulties in arranging satisfactory financing.

\section{DIVIDED INTERESTS UNDER THE CANADA OIL AND GAS ACT}

The Act refers to holders of interests and holders of shares in interests, and as discussed above, ${ }^{30}$ a "share" is defined as an "undivided share" in an interest. There does not appear to be any prohibition against holding something other than an undivided share of an interest, but the

49. Supra at Parts V. C., esp. discussion of ss. 30 (3).

50. Supra n. 27. 
Act contains no reference to what might be called "divided interests". The first step is to determine which interests in an exploration agreement or production licence may be considered to be "undivided" and which may be "divided".

While a "share" is an "undivided share" by definition, there is no definition or other indication of the meaning of "undivided share". A review of various legal dictionaries reveals that the phrase is commonly associated with land. The right of a tenant in common is of ten described as an undivided interest. It does not have to be equal as to value or quantity to that of a fellow tenant in common, but it extends over the whole and every part of the property. It is curious that a term usually employed to define interests in land is adopted in legislation which otherwise goes to elaborate lengths to ensure that agreement and licence holders acquire no interest in land.

There was no concept of an undivided share under the original Bill C20,31 and nothing in the Parliamentary debates helps clarify its intended meaning. 52

It is submitted that the distinction between "divided" and "undivided" shares refers to the contractual obligations held by interest holders with respect to the lands covered by an exploration agreement or production licence. If an interest owner allows a third party to farm in on the whole acreage of an exploration agreement by drilling an exploratory well, the third party will earn an "undivided" interest in the exploration agreement. If the third party earns an interest in only half of the acreage, it acquires a "divided" interest in the exploration agreement and benefits flowing from the unacquired half will not accrue to the third party. The rights in a "divided" interest are not entirely segregated, however. For example, if a holder of an interest in one-half of the lands defaults in its obligations, the Minister could cancel the entire exploration agreement. Or if rentals under a provisional lease were paid for only one-half of the acreage, the entire interest would be subject to forfeiture. But "undivided" must somehow qualify and narrow the class of shares of interests which by statute it modifies and it is reasonable to refer to the remainder of the class as "divided" interests. The distinction in the classes more likely refers to a division of rights with respect to the land covered by an interest than anything else.

The suggestion has been made that, as the Canada Oil and Gas Act deals only with "undivided" shares, it prohibits by implication the creation of "divided" shares in exploration agreements and production licences. ${ }^{53}$ But if the distinction between "divided" and "undivided" rights discussed above is accurate, then it will be difficult to support the notion of an implied prohibition of "divided interests", since the Minister has already approved the creation of several such interests.

51. Introduced in 1977. Bill C-20 died on the Order Paper.

52. However, on June 2, 1981. M. Lalonde in the Standing Committee on Natural Resources and Public Works respecting Bill C -48 (the Canada Oil and Gas ACt). in response to an inquiry as to whether "indivise" was appropriate in the French text. referred to "une part in. divise" as "sacramental wording in law".

53. Supran. 38 at 256. 
The so-called "leakage rules" under the PIP Regulations ${ }^{54}$ provide that in order to maintain maximum incentives, the farmee under a multiwell farmin must receive his full interest in a minimum land block around each well as soon as each well is completed. If, for some reason, a farmee completes one but not all of the required wells, he will have earned an interest in part but not all of the land covered by the exploration agreement. Accordingly, the farmee would hold a divided interest in the exploration agreement.

And at least one approved exploration agreement provides for optional participation in a well. If the option is not exercised by two of the holders, they will forfeit their interests in half of the lands covered by the agreement. They will retain "divided" interests in the exploration agreement as their rights will be confined to the half of the lands covered by the agreement where the earning well was not drilled.

It may be a little more difficult to create "divided" interests under production licences, because the licence will be granted only in respect of those lands to which a commercial discovery extends. ${ }^{55}$ But under a carefully drafted pooling agreement it may be possible for two interest holders to maintain their distinct interests in different areas covered by a production licence. Nothing in the pooling and unitization provisions of the Oil and Gas Production and Conservation Act ${ }^{56}$ appears to deprive working interest holders of their distinct interests.

If the above analysis is correct, and barring amendments to the Canada Oil and Gas Act, it may be possible for holders of "divided" shares in exploration agreements and production licences to avoid many of the controversial provisions and uncertainties of the National Energy Program, which Program the Canada Oil and Gas Act was intended to implement. Lenders to such holders will consider the possibility of retroactive legislation which might be passed to ensure equal treatment of holders of "divided" and "undivided" interests.

To examine the treatment of "divided" interests and "divided" interest holders under the Canada Oil and Gas Act, assume that Yankee Oil, with a COR of $20 \%$, and Maple Leaf Oil, with a COR of $80 \%$, each holds a one-half undivided interest in Exploration Agreement No. 1 ("E.A. No. 1") covering 100,000 acres on the Grand Banks. A commercial discovery is made in the centre of the lands covered by the exploration agreement. Yankee agrees to transfer all of its interest in the north half of E. A. No. 1 to Maple Leaf and Maple Leaf agrees to transfer all its interest in the south half to Yankee, so that Yankee will have a $100 \%$ interest in the south half, Maple Leaf a $100 \%$ interest in the north, and each will have a 50\% "divided" interest in E. A. No. 1.

54. Petroleum Incentives Program Regulations. SOR/82-666 as am., reproduced in C.C.H. Canadian Lid. Energy Program Reporter.

55. Supran. 2 at s. 18.

56. Oil and Gas Production and Conservation Act, R.S.C. 1970, c. 04, as am.. s5. 20 - 37. 
The consequences of these transfers under a strict interpretation of the present provisions of the Act are these:

1. The "interest" as defined in subsection 2(1) continues to be E. A. No. 1 .

2. Neither company has a "share" in E. A. No. 1 since a "share" is defined as an undivided share in an interest.

3. Neither company is a "holder" or an "interest holder" because neither holds an "interest" (an entire exploration agreement) or a "share in an interest" (an undivided share).

4. E. A. No. 1 has no "interest owner", since the definition of "interest owner" is the single holder of an entire agreement or licence, or the group of interest holders (holders of undivided shares).

5. Notice of the transfer agreements creating the divided interests does not have to be given to the Minister under section 52 because section 52 applies only to agreements which will result in a transfer, assignment or other disposition of an interest (an entire exploration agreement) or a share in an interest (an undivided share).

6. For the same reason, Ministerial approval is not required to maintain the force and effect of the transfer agreements. Assignments of divided interests to the companies' lenders would also be exempt from Ministerial approval.

7. The transfers do not have to be registered, as section 53 applies to the transfer of an "interest" or a "share in an interest".

8. By section 9, E. A. No. 1 confers the exclusive right, subject to compliance with the other provisions of the Act, to obtain a production licence. Section 18 does not apply, since it deals only with an application by an "interest owner" for a production licence. Accordingly, there is no requirement to prove to the satisfaction of the Minister that a commercial discovery exists. Only section 19 applies, as it requires the intended "beneficial owner of the production licence" to have a combined COR of $50 \%$ or more. Yankee and Maple Leaf together have a combined COR which satisfies section 19. Thus, Yankee and Maple Leaf are entitled to a production licence, even if the Minister is not satisfied that a commercial discovery exists.

9. The $25 \%$ Crown share is reserved to Her Majesty pursuant to subsections $27(2)$ and (3), but it is interesting to note that section 29 provides for a reduction in interest only with respect to "interest holders" and neither Yankee nor Maple Leaf meets that definition. Section 29 therefore raises the possibility that where a production licence is held by a combination of "divided" and "undivided" interest holders, the Crown share is taken solely from the "undivided" interest holders. This unbalanced reservation seems unfair, but the argument can be made that the Act specifically requires the Crown share to be taken from "undivided" interests. This argument would be particularly forceful if the 
federal government has approved the creation of the divided interests.

For the purpose of our example, assume that the Minister has transferred the Crown share to Petro-Canada and that Petro-Canada has converted the Crown share to a normal $25 \%$ undivided interest. The interests now stand as follows:

(a) Petro-Canada has a $25 \%$ undivided interest in Production Licence No. 1;

(b) Yankee Oil has a 37.5\% divided interest in the licence, being a $75 \%$ interest in the south half of lands covered thereby; and

(c) Maple Leaf Oil has a 37.5\% divided interest in the licence, being a $75 \%$ interest in the north half of lands covered thereby.

Hence, using the above analysis:

10. If both Yankee and Maple Leaf are taken over by U.S. companies and their respective Canadian ownership rates drop to zero, there will be no reduction in interest under section 23. Section 23 deals only with the COR of the "interest owner" and the only holder of an "undivided" share in Production Licence No. 1 is PetroCanada, whose COR remains $100 \%$.

11. While section 40 is somewhat confusing with respect to "divided" interest holders, Yankee and Maple Leaf may be required to pay the basic $10 \%$ royalty. However, under section 41 , only holders of "undivided" shares in production licences are subject to the progressive incremental royalty. As only Petro-Canada in our example holds such an "undivided" share, only Petro-Canada would be liable to pay $50 \%$ of its profit from Production Licence No. 1 to Her Majesty the Queen.

12. Finally, all three companies - Petro-Canada, Yankee Oil and Maple Leaf Oil - will be liable to the Crown for breaches of their contractual obligations under the production licence, but only the "undivided" interest holder, Petro-Canada, is liable to cancellation of its rights on default under section 55 of the Act.

There does not appear to be any rationale for a different treatment of "divided" and "undivided" shares in exploration agreements and production licences under the Canada Oil and Gas Act, but a strict interpretation of the Act reveals differences so great that we may expect an amendment to the definition of "share" in the Act. Until further clarification, lenders to holders of "divided" interests would be well advised to evaluate those interests on the basis that they are subject to the same Ministerial discretion and uncertainties as "undivided" interests.

\section{CONCLUSION}

As the rights which Canada enjoys under international law in respect of the natural resources of the continental shelf are less comprehensive than the onshore fee simple rights of ownership, Canada is justified in imposing a radically different system for the allocation of offshore rights, a system which is based on contract rather than on an absolute conveyance of real property rights. 
The contractual model admits more easily of residual Crown rights and powers over the exploration for, development of and production of natural resources from the continental shelf, as the broad discretionary powers retained by the Minister under the Canada Oil and Gas Act bear ample witness. The almost universal unhappiness expressed by the oil industry at the uncertainties created by such discretion will be matched, if not exceeded, by the concerns of lending institutions which are asked to finance the development of of fshore production facilities on the security of the project itself. Government flexibility and cooperation will be necessary to negotiate adequate restrictions to the Minister's broad discretionary powers, so that appropriate financing will be adequately secured by oil and gas rights whose nature, extent and value can be determined with some certainty. 